\title{
TINJAUAN KUALITAS PUPUK ORGANIK DAN PENGAWASANNYA BAGI KEAMANAN DAN KETAHANAN PANGAN DI INDONESIA
}

\author{
Agustian $^{1 *}$ \\ ${ }^{1)}$ Laboratorium Biologi Tanah Fakultas Pertanian Universitas Andalas \\ Kampus Limau Manis, Padang (25163) telp. 0751-72773, Fax. 0751-777061 \\ *Alamat korespondensi, email: agusti_an@yahoo.fr
}

\begin{abstract}
The use of organic fertilizers in agricultural production can not only increase soil fertility but also at the same time improve soil quality. Organic fertilizer is a unique product because it can improve physical properties, chemical, and biological soil as plant growth media. These characteristics bring the organic fertilizers into a valuable product that can be used in a variety of use. Today in Indonesia, there are so many outstanding varieties of organic fertilizer products either refined or imported products. Monitoring of the quality and feasibility of organic fertilizer materials is needed, so they will not harm the farmers as consumers. Each country develops criteria standard of organic fertilizer valuing each country's interest. United States, Canada, Australia and Europe use different compost quality criteria tailored to the needs and environmental rules that apply. So far in Indonesia rules used in determining quality is Permentan No. 02/Pert/HK.060/2/2006 which was then updated with Permentan No.28/PERMENTAN/OT.140/2/2009 on Organic Fertilizers and Soil Ameliorant. Basically, the appraisal made on the maturity and quality of organic fertilizers is based on observation of physical, chemical, and biological parameters. Review of the criteria used in the Regulation of the Minister of Agriculture was necessary in considering the criteria used which are very harmful to consumers, such as if it is satated that C-organic content is approximately $12 \%$, which is low, it means that there might exist some follow-up materials such as glass, plastic in the fertilizer about $2 \%$. If the rules are maintained, it will be very detrimental to Indonesia because of invasion from over seas. Import organic fertilizers would be siege to Indonesian farmers. Permentan No.28/PERMENTAN/SR.130/5/2009 has also set up institutions in charge of monitoring the quality of organic fertilizers. However, the quality control must be carried out. It is not only at the level of the end product, but it must also begin from the moment of the production process by establishing a supervisory agency competent. Since organic fertilizers can be produced by large industries, small and medium-scale farmers, the level of supervision is needed with different approaches.
\end{abstract}

Keywords: organic fertilizer, quality, processes and controls

PENDAHULUAN

Tantangan akan ketahanan pangan menjadikan sektor pertanian berperan penting dalam membangun sistem ketahanan pangan nasional yang tangguh. Upaya untuk memenuhi kecukupan dan perbaikan kualitas pangan dilakukan melalui berbagai cara antara lain melalui perbaikan akses petani terhadap sarana produksi seperti pupuk dan benih serta kemudahan dalam permodalan. Program Intensifikasi yang dilakukan selama ini dalam usaha peningkatan produksi pertanian tidak terlepas dari kontribusi pengadaan sarana produksi pertanian. Penerapan program pemupukan berimbang selain diharapkan dapat meningkatkan produksi pertanian dan produktivitas lahan juga sekaligus diharapkan dapat menghemat pemakaian pupuk buatan dan devisa negara.

Selama ini dalam mendukung pengembangan sektor pertanian terutama subsektor tanaman pangan dan hortikulutura, 
pemerintah menyediakan dana subsidi pupuk tunggal (Urea, SP-36 dan $\mathrm{KCl}$ ). Seiring dengan memburuknya perekonomian Indonesia semenjak tahun 1998 pemerintah mulai menerapkan secara bertahap penghapusan subsidi pupuk. Hal ini menyebabkan harga pupuk melambung tinggi tidak terkendali dan ketersediaan pupukpun menjadi langka di saat awal musim tanam sementara peningkatan produksi dengan pupuk buatan sudah mencapai titik jenuh karena ketidakimbangan hara. Kondisi ini menyebabkan pemerintah mulai mengembangkan kebijakan mencari pupuk alternatif pengganti pupuk buatan selain melakukan pengamanan kebutuhan pupuk melalui impor. Penggunaan pupuk organik sebagai pengganti pupuk buatan mulai digalakkan dan berbagai industri yang dulunya memproduksi pupuk buatanpun mulai beralih memproduksi pupuk organik dengan adanya subsidi disamping munculnya berbagai industri pupuk oraganik lainnya sebagai pemain baru.

\section{Pupuk organik, kompos dan pupuk hijau}

Pupuk organik merupakan semua produk yang dihasilkan dari pengolahan bahan organik asal tanaman dan hewan yang dapat dirombak menjadi hara yang tersedia bagi tanaman. Dalam Permentan No.28/PERMENTAN/SR.130/5/2009 tentang pupuk organik, pupuk hayati dan pembenah tanah dikemukakan bahwa pupuk organik adalah sebagian besar atau seluruhnya terdiri atas bahan organik yang berasal dari tanaman dan atau hewan yang telah melalui proses rekayasa, dapat berbentuk padat atau cair yang digunakan mensuplai bahan organik untuk memperbaiki sifat fisik, kimia dan biologi tanah. Bahan dengan kandungan C-organik yang rendah dan tidak masuk dalam ketentuan pupuk organik, maka diklasifikasikan sebagai pembenah tanah. Pembenah tanah atau soil ameliorant menurut Permentan adalah bahan-bahan sintetis atau alami, organik atau mineral.

Pupuk organik dapat berasal dari berbagai sumber bahan organik seperti sisa panen (jerami, brangkasan, tongkol, bagas tebu dan sabut kelapa), limbah ternak dan limbah industry berbasis produk pertanian dan sampah kota. Di Indonesia bahan organik sebagai bahan baku pupuk organik biasanya berasal dari sisa atau limbah panen hasil pertanian dan seringkali juga dari non pertanian. Hasil penelitian Kurnia et.al (2001) yang ditampilkan pada Tabel 1 . memperlihatkan asal bahan dan bentuk produk pupuk organik yang dihasilkan dari pengolahan bahan organik tersebut.

Kompos merupakan produk hasil dekomposisi dari limbah pertanian dan hewan yang dilakukan dengan bantuan mikroorganisme perombak (bakteri, fungi dan aktinomiset) sedangkan pupuk hijau

Tabel 1 . Sumber bahan dan bentuk pupuk organik yang umum digunakan di Indonesia

\begin{tabular}{|c|c|c|}
\hline Sumber & Asal bahan & Bentuk \\
\hline Pertanian & $\begin{array}{ll}\text { - } & \text { Pangkasan tanaman legum } \\
\text { - } & \text { Sisa hasil panen tanaman } \\
\text { - } & \text { Limbah ternak besar } \\
\text { - } & \text { Limbah ternak unggas } \\
\text { - } & \text { Kompos }\end{array}$ & $\begin{array}{l}\text { - Padat } \\
\text { - Padat } \\
\text { - Padat dan cair } \\
\text { - Padat } \\
\text { - Padat }\end{array}$ \\
\hline Nonpertanian & $\begin{array}{ll}\text { - } & \text { Limbah organik kota } \\
\text { - } & \text { Limbah penggilingan padi } \\
\text { - } & \text { Limbah organik pabrik gula } \\
\text { - } & \text { Limbah organik pabrik kayu } \\
& \text { (serbuk gergaji) } \\
\text { - } & \text { Gambut (abu bakar gambut) } \\
\text { - } & \text { Limbah pabrik bumbu masak }\end{array}$ & $\begin{array}{l}\text { - Padat dan cair } \\
\text { - Padat dan cair } \\
\text { - Padat dan cair } \\
\text { - Padat } \\
\text { - Padat } \\
\text { Padat dan cair }\end{array}$ \\
\hline
\end{tabular}

Sumber: Kurnia et al., 2001 
adalah bahan hijauan dari tanaman (daun dan batang) yang lunak yang memenuhi syarat sebagai puk hijau dan dapat langsung dibenamkan ke tanah sebagai pupuk.

Biasanya yang dijadikan pupuk hijau adalah tanaman kacang-kacangan yang memiliki kandungan $\mathrm{N}$ yang tinggi dan berbatang lunak sehingga dalam tanah cepat terombak. Pembuatan kompos sangat bermanfaat karena dapat merubah limbah organik yang tadinya dianggap menjadi polusi bagi lingkungan, menjadi subtansi yang bernilai. Kualitas kompos secara luas tergantung pada penanganan yang dilakukan. Untuk memperoleh pupuk kompos yang berkualitas diperlukan beberapa cara atau teknik yang harus diperhatikan secara baik.

\section{Proses pengomposan dan fungsinya}

Pengomposan merupakan suatu proses dekomposisi yang berlangsung secara aerobic dan lembab serta panas yang dibantu pelaksanaannya oleh mikrorganisme (secara biologis) yang dalam prosesnya merubah bahan organik menjadi senyawa-senyawa yang sederhana, melepaskan sejumlah hara (mineralisasi) yang dikandung bahan organik, menyisakan bahan-bahan organik yang resistan dan relatif stabil serta melepaskan karbon dioksida $\left(\mathrm{CO}_{2}\right)$. Kondisi lingkungan yang terkontrol selama proses dekomposisi merupakan pembeda terhadap dekomposisi yang berlangsung secara alami (Zucconi dan De Bertoldi, 1987). Aerasi dan kelembaban merupakan kondisi yang perlu dikontrol untuk mendapatkan temperatur $\left(55-60^{\circ} \mathrm{C}\right)$ dibutuhkan oleh mikroorganisme selama pengomposan (Chen and Inbar, 1993)

Lamanya waktu pengomposan
berkaitan erat dengan temperatur pengomposan dan karakteristik bahan yang dirombak. Jika bahan banyak mengandung bahan yang mudah dirombak maka proses dapat berlangsung dengan cepat, selanjutnya melambat jika bahan yang tersisa adalah bahan yang relatif sulit dirombak seperti selulosa dan lignin. Tingginya kandungan selulosa dan lignin dalam bahan memperlambat proses dekomposisi ( Palm and Sanchez, 1991).

Jika kondisi pengomposan telah sesuai, maka mikroganisme segera melaksanakan dekomposisidan temperatur mulai menaik. Dalam hal ini ketersediaan oksigen yang dicerminkan dengan aerasi bahan (5\% total bahan) dan kelembaban 40$65 \%$ serta ukuran bahan 1/8 sampai 2 inchi serta ratio $\mathrm{C} / \mathrm{N}>20$ merupakan hal yang dibutuhkan untuk proses dekomposisi yang baik (Rynk et. al. 1992)

Pada prinsipnya proses pengomposan dapat dibagi atas 2 tahap. Pada tahap pertama pengomposan (1-2 hari) merupakan tahap aktif, dimana kelompok mikroorganisme mesophilic (aktif pada rentang temperatur $35-45^{\circ} \mathrm{C}$ ) mulai menginisiasi dekomposisi senyawa organik Chen dan Inbar (1993) mengungkapkan setelah tahap aktif proses berlanjut ke tahap kedua yaitu tahap pematangan dimana tahap ini merupakan tahapan yang sangat penting dalam pengomposan. Pada tahapan ini aktivitas mikobia menyebabkan temperatur terus menaik sampai $55-60^{\circ} \mathrm{C}$. Pada kondisi ini mikrobia thermophilik berperan aktif dan merombak dengan cepat (sedapat mungkin temperatur dipertahankan sampai akhir pengomposan). Jika temperatur melebihi rentang temperature tersebut maka diperlukan pembalikan bahan untuk menjaga agar mikrobia thermophilik tidak mati.

Hal ini dibutuhkan karena sebenarnya berbagai proses penting yang menentukan kualitas kompos berlangsung selama tahap ini. Bahan organik mengalami kerusakan dan ukuran bahan berkurang, mikroba pathogen menjadi mati, biji gulma juga menjadi rusak serta larva serangga perusak juga dimatikan. Sementara $\mathrm{pH}$ kompos mulai menaik mencapai diatas 7 dengan mulai dilepaskannya ammonia sewaktu dekomposisi protein. Ketiaadaan tahap ini dalam proses pengomposan sangat mengurangi kualitas kompos yang dihasilkan mengingat peluang biji gulma, serta mikroba pathogen terhadap tanaman maupun manusia berpeluang masih hidup dan dapat berkembang baik jika digunakan nantinya sebagai pupuk. Setelah sebahagian besar bahan terurai, maka temperature secara perlahan-lahan mulai menurun. Pada saat inilah terjadinya pematangan kompos tingkat lanjut, volume dan biomassa bahan berkurang yang bias mencapai $30-40 \%$ volume awal. 


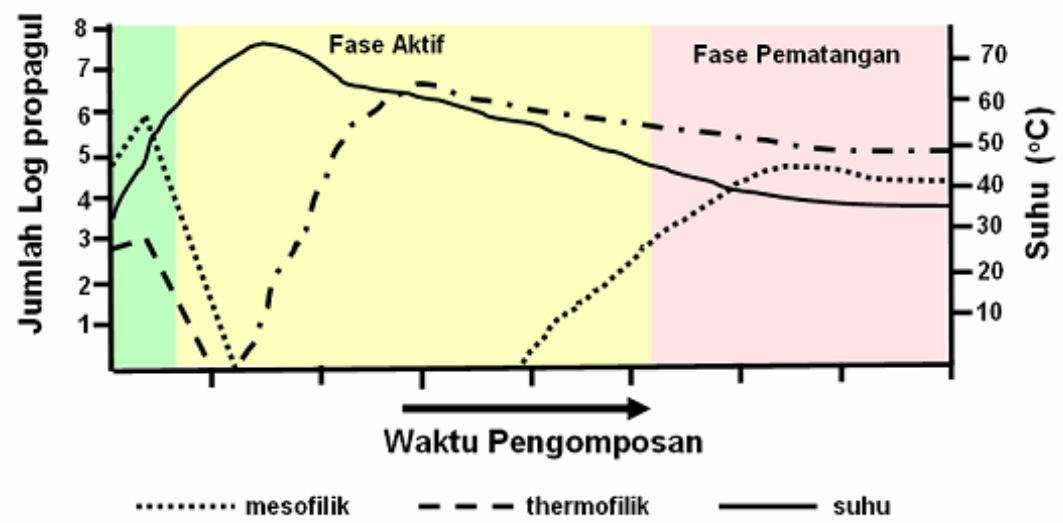

Gambar 1. Perubahan suhu dan dan jumlah mikroba selama pengomposan (Isroi, 2008)

\section{Ciri fisik Penentu Kematangan dan Kualitas kompos}

Stabilitas dan kematangan kompos menurut Isroi (2008) merupakan istilah yang sering digunakan untuk menetukan kualitas kompos. Stabilitas merujuk pada kondisi kompos yang sudah tidak mengalami dekomposisi dan secara perlahan unsur hara tanaman dilepas secara perlahan (slow release) ke dalam tanah. Stabilitas sangat penting untuk menentukan potensi ketersediaan hara di dalam tanah atau media tumbuh lainnya (Brinton, 2000). Sedangkan istilah kematangan mencerminkan tingkat kesempurnaan proses pengomposan. Pada kompos yang telah matang, bahan organic mentah telah terdekomposisi membentuk produk yang stabil.

Kematangan kompos telah menjadi parameter menentukan dalam menilai kualitas kompos. Alasannya adalah karena ketidakmatangan serta rendahnya stabilitas kompos menimbulkan banyak persoalan ditingkat penyimpanan, pemasaran dan penggunaannya. Di tingkat penyimpanan, kompos yang tidak matang setelah dikemas akan mengeluarkan bau tak sedap karena terjadinya proses perombakan secara anaerobic, yang ditandai dengan menggelembung dan pecahnya kantong pembungkus. Kompos yang tidak matang juga menyulitkan proses pengiriman karena menghasilkan panas. Selanjutnya jika digunakan sebagai pupuk pada tanaman akan memberikan dampak negatif dikarenakan akan berkurangnya oksigen di daerah perakaran dan terjadinya reduksi nitrogen atau munculnya senyawa yang fitotoksik. Dewasa ini diberbagai negara maju seperti Canada, Amerika dan negara Eropa sudah menyusun criteria dan persyaratan dalam menilai kualitas dan kematangan kompos secara detil. Walaupun antara masing-masing negara terdapat perbedaan-perbedaan rentang kandungan dan metoda yang digunakan dalam menilai tetapi usaha-usaha penyamaan terus dilakukan.

Untuk mengetahui tingkat kematangan kompos dapat dilakukan dengan uji laboratorium atau pun dengan pengamatan sederhana di lapangan. Berikut dipaparkan cara sederhana untuk mengetahui tingkat kematangan kompos.

\section{Dicium atau dibaui}

Kompos yang sudah matang berbau tanah dan harum, meskipun kompos dari sampah kota. Apabila kompos tercium bau yang tidak sedap berate terjadi fermentasi secara anaerobic yang menghasilkan senyawa-senyawa beracun yang membahayakan tanaman. Jika kompos masih berbau seperti bahan mentahnya berarti kompos belum matang.

\section{Warna kompos}

Warna kompos yang sudah matang adalah coklat kehitam-hitaman. Apabila kompos masih berwarna hijau atau warnanya mirip dengan bahan mentahnya berarti kompos tersebut belum matang.

\section{Penyusutan}


Terjadi penyusutan volume/ bobot kompos seiring dengan kematangan kompos. Besarnya penyusutan tergantung pada karakteristik bahan mentah dan tingkat kematangan kompos. Penyusutan yang terjadi biasanya berkisar antara 20-40\%. Jika penyusutan masih kecil atau sedikit, kemungkinan besar proses pengomposan belum selesai dan kompos belum matang.

\section{Tes kantong plastik}

Contoh kompos diambil dari bagian tumpukan, kemudian dimasukkan ke dalam kantong plastik, ditutup rapat dan disimpan di dalam suhu ruang selama kurang lebih satu minggu. Apabila setelah satu minggu kompos berbentuk baik, tidak berbau atau berbau tanah berarti kompos telah matang.

\section{Tes Perkecambahan}

Contoh kompos diletakkan dalam bak kecil atau dalam beberap pot kecil. Kemudian masukkan bebrapa benih (3-4 benih). Jumlah benih pada setiap potnya harus sama. Pada saat yang bersamaan kecambahkan juga beberapa benih di atas kapas basah yang diletakkan di dalam baki dan ditutup dengan kaca/plastic bening. Benih akan berkecambah dalam beberapa hari. Pada hari ke-5 atau ke-7 hitung benih yang berkecambah. Bandingkan jumlah kecambah yang tumbuh di dalam kompos dan di atas kapas basah. Kompos yang matang dan stabil ditunjukkan oleh banyaknya benih yang berkecambah.

\section{Suhu}

Suhu kompos yang sudah matang mendekati suhu awal pengomposan. Suhu kompos yang masih tinggi atau di atas $50^{\circ} \mathrm{C}$, berarti proses pengomposan masih berjalan aktif.

\section{Kandungan air kompos}

Kompos yang sudah matang memiliki kandungan air kurang lebih 55-65\%. Cara mengukur kandungan air kompos adalah sebagai berikut. Daimbil sambel kompos dan ditimbang berat awalnya, kemudian kompos dikeringkan di dalam oven atau microwave hingga beratnya konstan. Selanjutnya kompos ditimbang kembali dan berat tersebut merupakan berat kering. Kandungan air kompos dihitung dengan rumus berikut ini:

\section{Kandungan air (\%)= Berat basah - Berat Kering $\times 100 \%$ Berat kering}

\section{Parameter fisik lain dalam standarisasi pupuk organik yang perlu diperhatikan}

Tabel. 2 Kandungan maksimum bahan ikutan yang diperbolehkan dalam pupuk organik pada berbagai negara

\begin{tabular}{|c|c|c|}
\hline $\begin{array}{l}\text { Country with } \\
\text { standard }\end{array}$ & $\begin{array}{l}\text { Stones } \% \text { of } \\
\text { dry we ght }\end{array}$ & $\begin{array}{l}\text { Man-Made Foreign Matter } \\
\text { gass, plastic, metal, as\% of } \\
\text { dry weight }\end{array}$ \\
\hline Austra a & $\begin{aligned} & \text { must be }<5 \% \text { of } \\
&>5 \mathrm{~mm} \text { s ze }\end{aligned}$ & $\begin{array}{r}<0.5 \% \text { for }>2 \mathrm{~mm} \\
\text { faction }\end{array}$ \\
\hline Austria & $\begin{array}{l}\text { must be }<3 \% \text { of } \\
\quad>11 \mathrm{~mm} \text { size }\end{array}$ & $\begin{aligned} &<2 \% \text { o } \\
&>2 \mathrm{~mm} \text { fraction }\end{aligned}$ \\
\hline Beglum & $<2 \%$ & $\begin{array}{r}\text { no visble contaminant, max } \\
\qquad .5 \%>2 \mathrm{~mm}\end{array}$ \\
\hline France & - & $\begin{array}{r}\text { Max. Contamination } 20 \% ;<6 \% \text { f } \\
\text { of }>5 \mathrm{~mm} \text { fraction }\end{array}$ \\
\hline Germany & $\begin{array}{r}\text { must be }<5 \% \text { of } \\
>5 \mathrm{~mm} \text { size }\end{array}$ & $\begin{array}{r}<0.5 \% \text { for }>2 \mathrm{~mm} \\
\text { faction }\end{array}$ \\
\hline $\operatorname{tat} y$ & - & $<3 \%$ tota \\
\hline Netheriands & $\begin{array}{r}\text { must be }<3 \% \text { of } \\
<5 \mathrm{~mm} \text { size }\end{array}$ & $\begin{aligned}<0.5 \% \text { for } & >2 \mathrm{~mm} \\
& \text { faction }\end{aligned}$ \\
\hline Spain & - & "free of contamination" \\
\hline Switzeriand & $\begin{array}{r}\text { must be }<5 \% \text { of } \\
>5 \mathrm{~mm} \text { size }\end{array}$ & $\begin{array}{r}<0.5 \% \text { for }>2 \mathrm{~mm} \text { fraction: max } \\
0.1 \% \text { pastic }\end{array}$ \\
\hline United Kingdom & $<5 \%>2 \mathrm{~mm}$ & $\begin{array}{l}<1 \%>2 \mathrm{~mm} \\
<0.5 \% \text { if p astc }\end{array}$ \\
\hline
\end{tabular}

Sumber: Brinton (2000) 
Jumlah bahan ikutan dalam kompos antar negara walaupun selalu didebatkan namun pada prinsipnya semua negara sepakat untuk membatasi sampai kadar yang rendah sampai sangat rendah. Biasanya kerikil, gelas dan plastik dimasukkan kedalam bahan ikutan. Batasan yang sering digunakan adalah dari segi ukuran dan jumlahnya.

Persyaratan lainnya yang perlu menjadi perhatian pokok dalam menetapkan pupuk organic adalah kandungan bahan organik dari pupuk organik. Kriteria yang dipakai sebagai acuan dalam produksi pupuk organik di Indonesia seperti diatur dalam PERMNTAN No.28/PERMENTAN/SR.130 /5/2009 sangatlah lemah. Penetapan batas terendah kandungan C-organik dari bahan $>12 \%$ sangatlah tidak berdasar sama sekali. Kandungan C-organik bahan >12\% mengandung arti bahwa pupuk organik boleh hanya mengandung bahan organik minimal $\pm 20 \%$ saja, sehingga dalam pupuk organik diberi kesempatan menambahkan bahan lain yang bukan organik sebanyak $80 \%$ dari bahan. Aturan yang berlaku saat ini sangat rentan dimanfaatkan oleh produsen yang kurang bertanggungjawab dan akan merugikan petani sebagai konsumen dan merupakan ancaman bagi produksi pertanian khususnya pangan dan lebih lanjut terhadap ketahanan pangan di Indonesia.

\section{Kualitas Kompos}

Kualitas kompos selain ditentukan oleh tingkat kematangannya juga ditentukan kandungan hara kompos yang dihasilkan. Kandungan hara ini sangat ditentukan baku mutu bahan organik yang digunakan sebagai bahan kompos. Bahan baku yang berbeda akan menghasilkan kandungan hara kompos yang berbeda juga. Pada Tabel 3. dapat dilihat kandungan hara pada berbagai bagian tanaman.

Karena yang biasa digunakan sebagai bahan baku kompos adalah bahan limbah atau sisa-sisa panen (batang, tongkol, sekam dan lainnya) maka kadar hara kompos yang dihasilkanpun akan menjadi rendah. Beragamnya bahan baku yang tersedia yang dapat diproses menjadi pupuk organik menyebabkan beragam juga kualitas kompos yang dihasilkan dari waktu ke waktu. Oleh sebab itu, di negara-negara maju pengawasan terhadap kualitas kompos sudah dimulai dari proses produksi dan uji petik dilakukan secara berkala dan diatur dalam suatu aturan yang jelas.

Tabel 3. Kandungan hara makro dan mikro pada beberapa tanaman

\begin{tabular}{|c|c|c|c|c|c|c|c|c|c|c|}
\hline Tanaman & $\mathrm{N}$ & $P$ & $\mathrm{~K}$ & $\mathrm{Ca}$ & $\mathrm{Mg}$ & $\mathrm{Fe}$ & $\mathrm{Cu}$ & $\mathrm{Zn}$ & $\mathrm{Mn}$ & $B$ \\
\hline & & & $\%$ & & - & \multicolumn{5}{|c|}{$\mathrm{mg} \mathrm{kg}^{-1}$} \\
\hline Gandum & 2,80 & 0,36 & 2,26 & 0,61 & 0,58 & 155 & 28 & 45 & 108 & 23 \\
\hline Jagung & 2,97 & 0,30 & 2,39 & 0,41 & 0,16 & 132 & 12 & 21 & 117 & 17 \\
\hline Kc. tanah & 4,59 & 0,25 & 2,03 & 1,24 & 0,37 & 198 & 23 & 27 & 170 & 28 \\
\hline Kedelai & 5,55 & 0,34 & 2,41 & 0,88 & 0,37 & 190 & 11 & 41 & 143 & 39 \\
\hline Kentang & 3,25 & 0,20 & 7,50 & 0,43 & 0,20 & 165 & 19 & 65 & 160 & 28 \\
\hline Ubi jalar & 3,76 & 0,38 & 4,01 & 0,78 & 0,68 & 126 & 26 & 40 & 86 & 53 \\
\hline Jerami padi & 0,66 & 0,07 & 0,93 & 0,29 & 0,64 & 427 & 9 & 67 & 365 & - \\
\hline Sekam & 0,49 & 0,05 & 0,49 & 0,06 & 0,04 & 173 & 7 & 36 & 109 & - \\
\hline Bt. jagung & 0,81 & 0,15 & 1,42 & 0,24 & 0,30 & 186 & 7 & 30 & 38 & - \\
\hline Bt.gandum & 0,74 & 0,10 & 1,41 & 0,35 & 0,28 & 260 & 10 & 34 & 28 & - \\
\hline Serbuk kayu & 1,33 & 0,07 & 0,60 & 1,44 & 0,20 & 999 & 3 & 41 & 259 & - \\
\hline
\end{tabular}




\section{Persyaratan pupuk organik berdasarkan Peraturan Menteri Pertanian RI No.28/PERMENTAN/SR.130/5/2009.}

Kebijakan standarisasi pupuk organik sangat diperlukan untuk menghindari terjadinya penipuan terhadap petani atas nama pupuk organik berlabel. Kebijakan ini sangat penting tidak saja untuk menghindari terjadinya penipuan tetapi juga untuk mencegah membanjirnya berbagai produk pupuk organik dari luar negeri. Sekarang ini sudah tercatat lebih dari

Tabel. 4. Ciri kimia pupuk organik yang berlaku di Indonesia sesuai dengan Peraturan Menteri Pertanian No.28/PERMENTAN/SR.130/5/2009

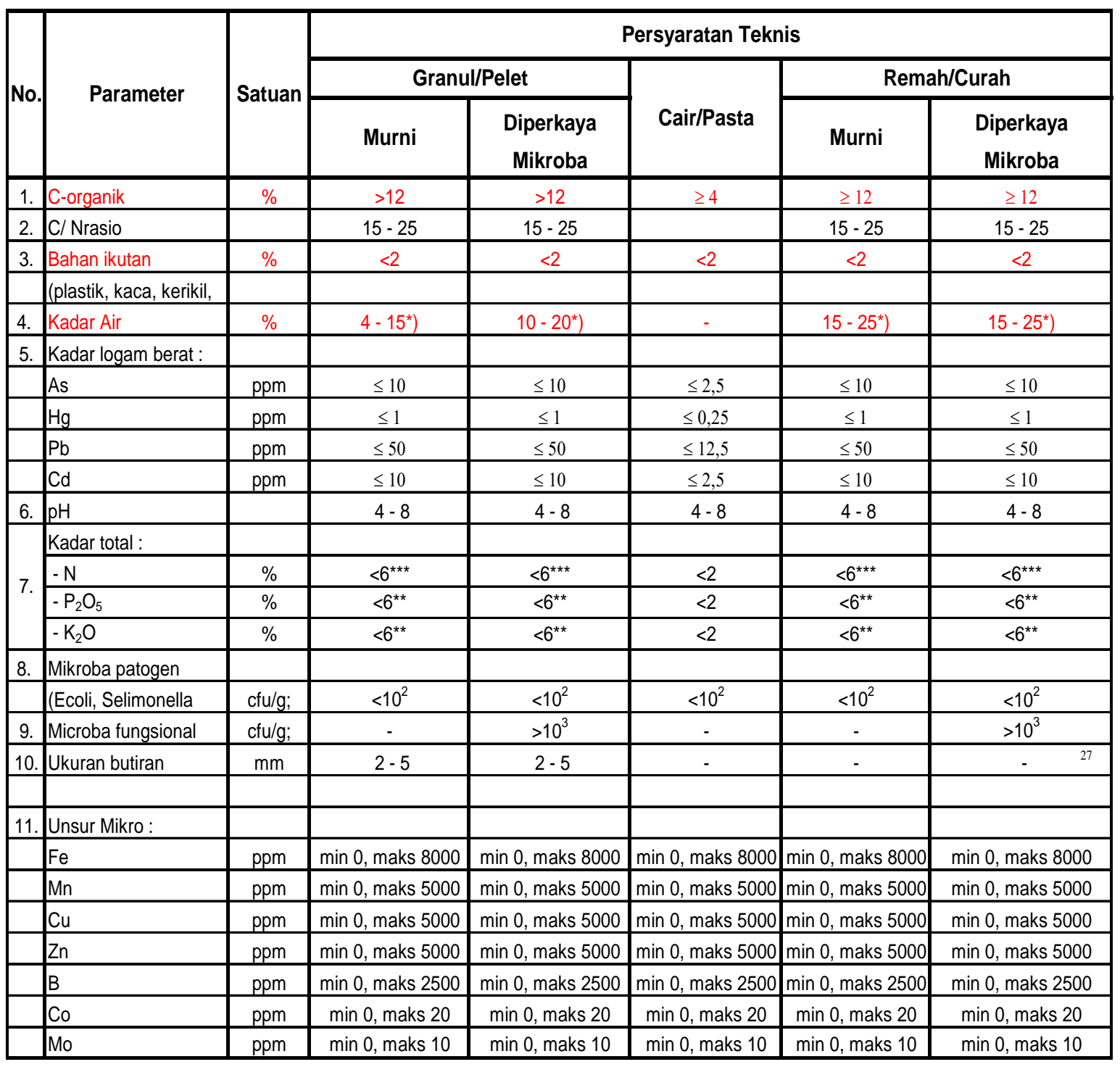

\section{Keterangan :}

*) Kadar air berdasarkan bobot asal

**) Bahan-bahan tertentu yang berasal dari bahan organik alami diperbolehkan mengadung kadar $\mathrm{P}_{2} \mathrm{O}_{5}$ dan $\mathrm{K} 2 \mathrm{O}>60 \%$ (dibuktikan dengan hasil laboratorium)

***) N-total=N-organik+N-NH4+N-NO3; Nkjeldahl=N-organik+N-NH4; C/N, N=N-total 
53 perusahaan yang memproduksi pupuk organik dengan berbagai merek dagang. Sementara itu kuat dugaan diantara pupuk organik yang beredar di pasaran mengandung timbal $(\mathrm{Pb})$ yang tinggi.

$$
\text { Peraturan Menteri Pertanian }
$$

No.28/PERMENTAN/SR.130/5/2009 telah memberikan batasan terhadap kandungan hara makro dan mikro dalam pupuk organik dan batas maksimal logam-logam berat seperti Pb, Co dan Cd. Namun demikian batasan-batasan yang disebutkan dalam Permentan tersebut perlu lebih dipertegas untuk menghindari adanya manipulasi terhadap pupuk organik.

\section{Kualitas Kompos berdasarkan Standar Nasional Indonesia}

Tabel 5. Standar kualitas kompos (SNI 19-7030-2004)

\begin{tabular}{|c|c|c|c|c|}
\hline No & Parameter & Satuan & Minimum & Maksimum \\
\hline 1 & Kadar Air & $\%$ & - & 50 \\
\hline 2 & Temperatur & $\mathrm{OC}$ & & suhu air tanah \\
\hline 3 & Warna & & & kehitaman \\
\hline 4 & Bau & & & berbau tanah \\
\hline 5 & Ukuran partikel & $\mathrm{mm}$ & 0,55 & 25 \\
\hline 6 & Kemampuan ikat air & $\%$ & 58 & - \\
\hline 7 & $\mathrm{pH}$ & & 6,80 & 7,49 \\
\hline \multirow[t]{2}{*}{8} & Bahan asing & $\%$ & $*$ & 1,5 \\
\hline & Unsur makro & & & \\
\hline 9 & Bahan organik & $\%$ & 27 & 58 \\
\hline 10 & Nitrogen & $\%$ & 0,40 & - \\
\hline 11 & Karbon & $\%$ & 9,80 & 32 \\
\hline 12 & Phosfor (P2O5) & $\%$ & 0.1 & - \\
\hline 13 & $\mathrm{C} / \mathrm{N}$-rasio & & 10 & 20 \\
\hline \multirow[t]{2}{*}{14} & Kalium (K2O) & $\%$ & 0,20 & $*$ \\
\hline & Unsur mikro & & & \\
\hline 15 & Arsen & $\mathrm{mg} / \mathrm{kg}$ & $*$ & 13 \\
\hline 16 & Kadmium (Cd) & $\mathrm{mg} / \mathrm{kg}$ & * & 3 \\
\hline 17 & Kobal (Co) & $\mathrm{mg} / \mathrm{kg}$ & * & 34 \\
\hline 18 & Kromium (Cr) & $\mathrm{mg} / \mathrm{kg}$ & * & 210 \\
\hline 19 & Tembaga (Cu) & $\mathrm{mg} / \mathrm{kg}$ & * & 100 \\
\hline 20 & Merkuri (Hg) & $\mathrm{mg} / \mathrm{kg}$ & $*$ & 0,8 \\
\hline 21 & Nikel (Ni) & $\mathrm{mg} / \mathrm{kg}$ & $*$ & 62 \\
\hline 22 & Timbal $(\mathrm{Pb})$ & $\mathrm{mg} / \mathrm{kg}$ & $*$ & 150 \\
\hline 23 & Selenium (Se) & $\mathrm{mg} / \mathrm{kg}$ & * & 2 \\
\hline \multirow[t]{2}{*}{24} & Seng $(Z n)$ & $\mathrm{mg} / \mathrm{kg}$ & $*$ & 500 \\
\hline & Unsur lain & & & \\
\hline 25 & Kalsium & $\%$ & $*$ & 25.5 \\
\hline 26 & Magnesium (Mg) & $\%$ & $*$ & 0.6 \\
\hline 27 & Besi (Fe) & $\%$ & $*$ & 2 \\
\hline 28 & Aluminium ( $\mathrm{Al}$ ) & $\%$ & $*$ & 2.2 \\
\hline \multirow[t]{2}{*}{29} & Mangan (Mn) & $\%$ & $*$ & 0.1 \\
\hline & Bakteri & & & \\
\hline 30 & Fecal Coli & $\mathrm{MPN} / \mathrm{gr}$ & & 1000 \\
\hline 31 & Salmonella sp. & $\mathrm{MPN} / 4 \mathrm{gr}$ & & 3 \\
\hline
\end{tabular}

Keterangan : * Nilainya lebih besar dari minimum atau lebih kecil dari maksimum 


\section{Perbaikan kualitas kompos dan regulasi produksi dan pengawasan}

Tabel 6. Kandungan hara beberapa jenis pupuk organik

\begin{tabular}{|c|c|c|c|c|c|c|c|}
\hline No & Jenis pupuk & $\mathrm{N}$-total & $\mathrm{P}_{2} \mathrm{O}_{3}$ & $\mathrm{~K}_{2} \mathrm{O}$ & C-organik & $\mathrm{C} / \mathrm{N}$ rasio & Kadar air \\
\hline & & & & $\%-$ & & & $\%$ \\
\hline 1. & Sp organik & 0,06 & 10,96 & 0,06 & 5,06 & 84 & 13,28 \\
\hline 2. & Kotoran ayam & 1,17 & 1,87 & 0,38 & 7,16 & 6,1 & 13,01 \\
\hline 3. & Pupuk organik KJD & 0.97 & 2,08 & 1,21 & 9,85 & 10,1 & 25,34 \\
\hline 4. & P-organik OCP & 9,07 & 8,58 & 6,13 & 15,82 & 1,7 & 16,23 \\
\hline 5. & Kompos AU & 2,03 & 0,34 & 3,25 & 17,83 & 8,8 & 13,10 \\
\hline 6. & Pelet & 2,69 & 8,25 & 7,02 & 12,25 & 4,7 & 9,23 \\
\hline 7. & Sipramin miwon & 4,57 & 0,17 & 1,73 & 6,94 & 2,0 & - \\
\hline 8. & PO semigrup & 0,63 & 1,86 & 1,08 & 9,21 & 14,26 & 42,98 \\
\hline 9. & P. raya cair & 4,07 & 0,18 & 1,03 & 4,80 & 1,2 & - \\
\hline 10. & Alfinase & 0,81 & 4,47 & 1,09 & 19,02 & 23,5 & 22,54 \\
\hline 11. & Fine compost & 0,68 & 1,40 & 1,09 & 5,04 & 7,4 & 46,43 \\
\hline 12. & P.raya padat & 2,25 & 0,46 & 0,57 & 11,9 & 5,3 & 37,96 \\
\hline 13. & Bokbsi & 0,73 & 0,62 & 1,0 & 9,39 & 12,9 & 43,86 \\
\hline 14. & PO granula 1 & 6,57 & 4,76 & 3,9 & 20,2 & 3,1 & 13,79 \\
\hline 15. & PO granula 2 & 6,08 & 4,9 & 4,3 & 21,2 & 4,3 & 11,25 \\
\hline 16 & Organik 3 & 0,18 & 11,04 & 0,39 & 4,56 & 25 & 31,84 \\
\hline 17 & Organik 4 & 1,54 & 7,34 & 0,41 & 10,3 & 7 & 40,9 \\
\hline 18 & Organik 5 & 1,89 & 1,9 & 0,27 & 12,89 & 7 & 57,1 \\
\hline 19 & Organik 6 & 0,61 & 0,3 & 0,09 & 4,11 & 7 & 26,58 \\
\hline 20 & Organik 7 & 1,38 & 0,2 & 0,09 & 6,28 & 5 & 34,24 \\
\hline 21 & Kompos & 0.37 & 0,77 & 8,95 & 8,95 & 14 & 62,86 \\
\hline
\end{tabular}

Sumber: Suriadikarta dan Setyorini (2005)

Hasil penelitian Suriadikarta dan Setyorini (2005) pada Tabel 5 dan Tabel 6, menemukan besarnya variasi kadar hara makro dan mikro pupuk organik yang beredar di Indonesia. Berpedoman pada hasil analisis kadar hara dari sembilan belas (19) contoh pupuk.

organik dan dua (2) pupuk cair yang diteliti, hanya tujuh (7) yang memenuhi syarat sebagai pupuk organik bila ditinjau dari segi kandungan C-organiknya.

Tabel. 5. Kandungan hara makro, C-organik dan kadar air beberapa contoh pupuk organik yang ditelitiMerujuk kepada kriteria pupuk organik pada Permentan No. 28 tahun 2009 tentang Pupuk Organik, Pupuk Hayati dan Pembenah Tanah, maka hanya satu dari pupuk organik yang beredar tersebut bisa digolongkan sebagai pupuk organik. Besarnya variabilitas dan rendahnya kadar hara makro dan mikro dalam contoh pupuk memberikan gambaran bahwa pengawasan terhadap mutu pupuk organik sangat urgent dilaksanakan.
Penggunaan pupuk organik yang berkualitas rendah oleh petani menimbulkan resiko turunnya produksi yang akan menganggu ketercapaian ketahanan pangan yang dicanangkan.

Oleh sebab itu pemerintah dalam hal ini Departemen Teknis Pusat dan Daerah yang berperan dalam membuat berbagai kebijakan dan program perlu membuat kebijakan menciptakan kondisi yang mendorong terjadinya peningkatan produksi, distribusi dan penggunaan pupuk organik mulai dari penggunaan teknologi tepat guna dalam pembuatan pupuk organik, pemberian subsidi pupuk organik yang efektif, regulasi atas produksi, distribusi dan pengawasannya. Disamping itu programprogram pembangunan pertanian lainnya yang lebih memberdayakan potensi masyarakat tani dalam usaha menciptakan pertanian berwawasan agribisnis yang berkelanjutan perlu lebih diutamakan. Pemerintah perlu memediasi antara kepentingan swasta dan kepentingan 
Tabel 7. Kadar hara mikro dan logam berat beberapa pupuk organik yang diteliti

\begin{tabular}{|c|c|c|c|c|c|c|c|c|}
\hline No & Jenis pupuk & $\mathrm{Fe}$ & $M n$ & $\mathrm{Cu}$ & $\mathrm{Zn}$ & $\mathrm{B}$ & $\mathrm{Pb}$ & $\mathrm{Cd}$ \\
\hline & & & & & $\mathrm{pm}-$ & & & \\
\hline 1. & Sp organik & 3.572 & 157 & 16 & 48 & 38 & 3 & 11 \\
\hline 2 & Kotoran ayam & 8.054 & 670 & 78 & 245 & 16 & 5 & 0,5 \\
\hline 3. & Pupuk organik KJDP & 5.420 & 396 & 181 & 185 & 24,3 & 3,2 & 1,2 \\
\hline 4. & P-organik OCF & 651 & 979 & 106 & 209 & 19,2 & 5,3 & 0,6 \\
\hline 5. & Kompos AU & 6.518 & 703 & 84 & 196 & 4,1 & 7,9 & to \\
\hline 6. & Pelet & 9.525 & 1.837 & 149 & 122 & 9,5 & 5,5 & 1,0 \\
\hline 7. & Sipramin miwon & 215 & 17 & 3 & 10 & 15,3 & 0,8 & to \\
\hline 8. & PO semigrup & 13.275 & 805 & 137 & 46 & 20,4 & 1,2 & 0,8 \\
\hline 9. & P. raya cair & 217 & 22 & 4 & 13 & 19,2 & td & to \\
\hline 10. & Alfingse & 11.496 & 154 & 99 & 42 & 24,6 & 7,6 & 0,7 \\
\hline 11. & Fine compost & 8.927 & 678 & 50 & 145 & 35,7 & 5,4 & to \\
\hline 12. & P. raya & 4.083 & 148 & 11 & 124 & 21,4 & td & to \\
\hline 13. & Boksahi & 8.837 & 427 & 137 & 137 & 31,2 & td & 0,1 \\
\hline 14. & Granula organik 1 & 5.316 & 357 & 78 & 107 & 32 & 6,2 & 1,3 \\
\hline 15. & Granula organik 2 & 6.113 & 372 & 80 & 110 & 39 & 5,7 & 1,0 \\
\hline 16. & Organik 3 & 39.228 & 3.457 & 990 & 565 & 23 & 18,5 & 1,5 \\
\hline 17. & Organik 4 & 8.456 & 1.823 & 654 & 841 & 48 & 4,8 & 1,6 \\
\hline 18. & Organik 5 & 6.762 & 896 & 110 & 215 & 38 & 4,3 & 0.1 \\
\hline 19. & Organik 6 & 24.116 & 191 & 20 & 38 & 25 & 4,2 & to \\
\hline 20. & Organik 7 & 3.682 & 24 & 23 & 33 & 18 & 1,5 & to \\
\hline 21. & Kompos & 5.569 & 301 & 18 & 41 & 22 & 2,2 & to \\
\hline
\end{tabular}

Sumber: Suriadikarta dan Setyorini (2005)

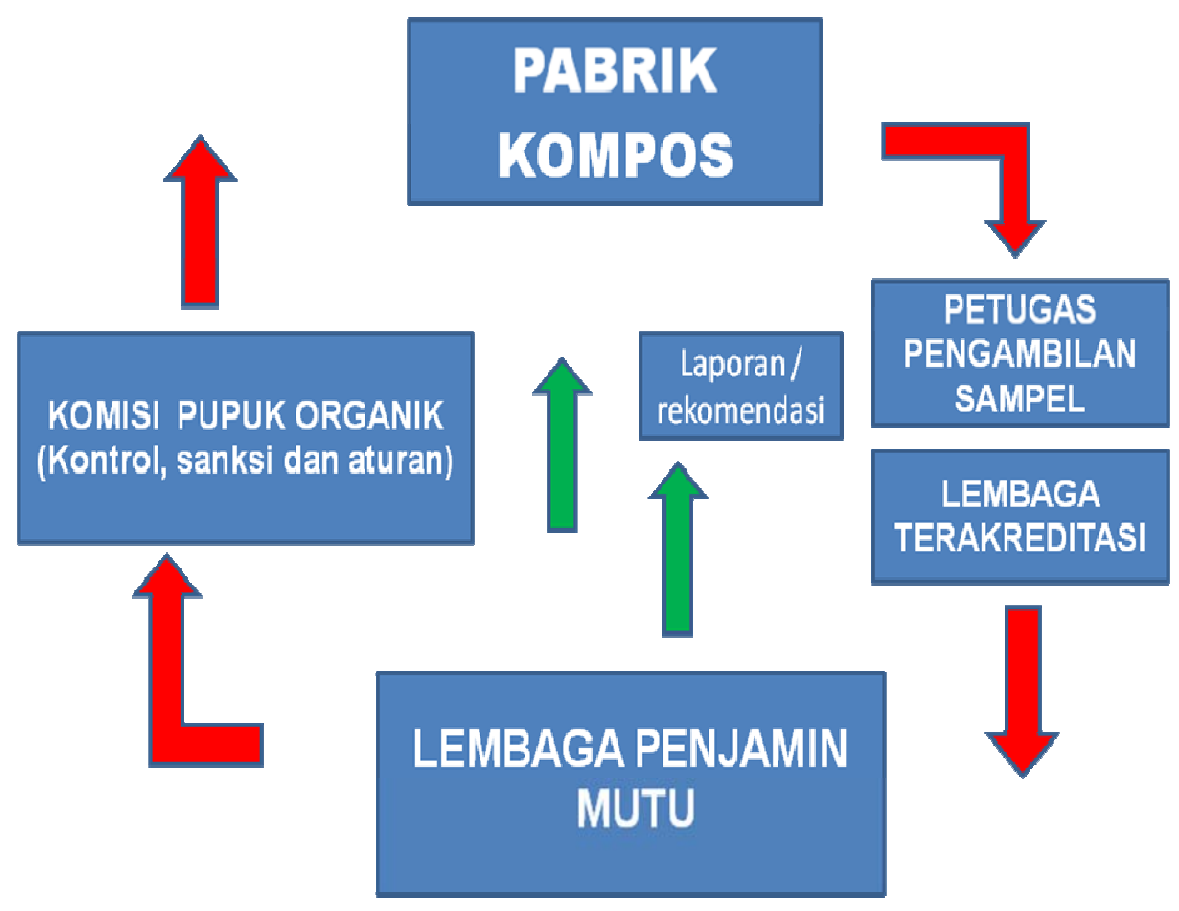

Gambar 1. Lembaga dan aliran pengawasan produksi dan mutu pupuk organik 
masyarakat petani dalam rangka pengembangan produksi, distribusi dan perluasan penggunaan pupuk organik secara massal. Hal ini penting untuk memberikan jaminan kualitas pupuk organik yang dihasilkan secara pabrikasi atau petani dapat menggunakan pupuk organik yang diproduksi sendiri dengan menggunakan teknologi yang sesuai dan menguntungkan.

\section{Lembaga pengawasan produksi dan kualitas pupuk organik}

Di Indonesia sejauh ini belum ada lembaga yang dibentuk khusus dan bertanggung jawab dalam pengawasan mulai dari proses pengolahan sampai tingkat pengedaran dan pemasarannya. Sebagai negara yang masih mengandalkan perekomiannya terhadap pertanian dan menjamin ketahanan pangan adalah sangat penting dibentuk suatu lembaga yang bertanggung jawab dalam pengawasan pupuk organik dengan aturan dan kewenangan yang jelas. Alur pengawasan terhadap proses produksi pupuk organik demi menjamin kualitas produk yang dihasilkan sehingga tidak merugikan petani dan program ketahanan pangan diusulkan seperti pada Gambar 1.

\section{UCAPAN TERIMAKASIH}

Tulisan ini telah dipresentasikan dan dibahas dalam Focus Group Discussion (FGD) antara berbagai stake holder pertanian yang diselenggarakan bersama oleh Dewan Tani Indonesia dengan Universitas Andalas tanggal 21 Januari 2010 bertempat di kampus Unand Limau Manis dalam rangka persiapan peluncuran subsidi pupuk organik.

\section{DAFTAR PUSTAKA}

Anonim. 2009. Peraturan Menteri Pertanian Nomor. 28/SR.130/5/2009 Tentang Pupuk Organik, Pupuk Hayati dan Pembenah Tanah

Badan Standarisasi Nasional (BSN). 2004. Spesifikasi Kompos dari Sampah Organik Domestik. SNI 19-7030-2004

Brinton W.F. 2000. Compost Quality Standards and Guidelines; Compost Quality in America. Woods End Research Laboratory Inc.
CCME. 2005. Guidelines fo Compost Quality. Canadian Council of Ministers of the Environment. Winnipeg-Canada

Chen, Y and U. Inbar. 1993. Chemical and spectroscopical analyses of organik matter transformation during composting in eelation to compost maturity. In. H.A.J. Hoitink and H.M. Keener (Eds.) Science and Engineering of Compostting: Design, Environmental, Microbiological and Utilization Aspects. Pp 550-560. Renaissance Publications Worthington. $\mathrm{OH}$

Kurnia, U., D. Setyorini, T. Prihatini, S. Sutono dan H. Suganda. 2001. Perkembangan dan penggunaan pupuk oraganik di Indonesia. Makalah pada Rapat Koordinasi Penerapan Penggunaan Pupuk Organik. Direktorat Pupuk dan Pestisida. Direktorat Jendral Bina Sarana Pertanian. Jakarta. Nopember 2001 (tidak dipublikasikan)

Palm, C.A dan P.A Sanchez. 1991. Nitrogen release from the leaves of some tropical legumes as affected by their lignin and polyphenolic contents. Soil Bio. and Biochem. 223: 83-88

Rynk, R., M. van de kamp., G.G. Wilson, M.E. Singley, T.L. Richard, J.J. Kolega, F.R. Gouin, L. Laliberty Jr., D Kay, D. Murphy, H.A.J. Hoitink, and W.F Brinton. 1992. On Farm Composting Handbook. R.Rynk (Eds.). NRAES-54. 186 p. Natural Resource, Agriculture and Engineering Service. Ithaca. N.Y

Suriadikarta, D.A dan D. Setyorini.2005. Laporan Hasil Penelitian Standar Mutu Pupuk Organik. Balai Penelitian Tanah. Bogor

Tan, K.H. 1994. Environmental of Soil Science. Marcel Dekker Inc. New York 10016. USA

Zucconi, F. and M. de Bertoldi. 1987. Compost specifications for the production and characterization of compost from municipal solid waste. 
In M. de Bertoldi et. Al (Eds.) Compost: Production, Quality and
Use. Pp 30-50. Elsevier Applied

Science. London 